\title{
INVESTIGATION OF THE HYDROPHOBIC PROPERTIES OF PIEZOELECTRIC NANOCOMPOSITES AND APPLICATIONS IN BIOMEDICAL MICRO-HYDRAULIC DEVICES
}

\author{
RAZISKAVA HIDROFOBNIH LASTNOSTI PIEZOELEKTRIČNEGA \\ KOMPOZITA IN NJEGOVA UPORABA ZA BIOMEDICINSKE \\ MIKROHIDRAVLIČNE NAPRAVE
}

\author{
Yatinkumar Patel', Giedrius Janušas', Arvydas Palevičius', Andrius Vilkauskas, \\ Petr Lepsik ${ }^{2}$ \\ ${ }^{1}$ Faculty of Mechanical Engineering and Design, Kaunas University of Technology, Studentu St. 56, Kaunas, Lithuania, LT-51424 \\ ${ }^{2}$ Faculty of Mechanical Engineering, Technical University of Liberec, Studentska 1402/2, Liberec, Czech Republic, 46117
}

Prejem rokopisa - received: 2019-10-15; sprejem za objavo - accepted for publication: 2020-02-12

doi:10.17222/mit.2019.249

\begin{abstract}
The main purpose of the paper is to investigate the hydrophobic properties of piezoelectric composites that could be used in biomedical micro-hydraulic devices. Hydrophobicity plays an important role, and gives less obstruction to the water, which is the major reason behind the lower efficiency of electrical devices, particularly for piezoelectric polymers. Hydrophobicity is an important property for the improvement in effectiveness and durability of microhydraulic devices made from PZT composite materials. To develop the PZT composite material, we began with the lead zirconate titanate (PZT) nanopowder synthesis. The PZT was additionally blended with three different binding polymers polyvinyl butyral (PVB), polymethyl methacrylate (PMMA), and polystyrene (PS) in benzyl alcohol to prepare a screen-printing paste. Then, by applying the screen-printing method, three different PZT coatings were prepared on aluminum and polyethylene terephthalate (PET). The hydrophobicity of the prepared PZT composite was made using a contact-angle measurement between the drop of water and three PZT composite materials PZT + PVB, PZT + PMMA, and PZT + PS. Also, the contact-angle measurement made with the drop of glycerin, spirit, and olive oil on three different PZT composites. Finally, the model of the micro-channel was created using COMSOL Multiphysics with the PZT + PMMA and simulated by applying the electrical excitation signal on the pattern of electrodes. The different wave-shaped deformations were achieved from the simulation of the microchannel. The proposed application could be used for bioparticle transportation.
\end{abstract}

Keywords: piezoelectric nanocomposite, hydrophobicity, contact angle, microhydraulic systems, microchannel, bioparticles

Avtorji v članku opisujejo raziskavo hidrofobnih lastnosti piezoelektričnih kompozitov, ki bi se lahko uporabljali v biomedicinskih hidravličnih napravah. Hidrofobnost je lastnost različnih snovi, da odbijajo vodo. Ta je slaba v primeru piezoelektričnih polimerov, kar je glavni razlog manjše učinkovitosti električnih naprav (sistemov), ki jih vsebujejo. Dobra hidrofobnost je pomembna lastnost za izboljšanje učinkovitosti in trajnosti mikrohidravličnih naprav, izdelanih iz kompozitnih materialov na osnovi Pb-Zr-titanatov (PZT). Izhodišče za razvoj PZT kompozitnega materiala je svinčev-cirkonijev titanatni nanoprah. Le-tega so avtorji dodatno mešali s tremi različnimi polimernimi vezivi na osnovi polivinil butirala (PVB), polimetil metakrilata (PMMA) ter polisterena (PS) v benzil alkoholu in s tem pripravili paste za sitotisk. Nato so, z metodo sitotiska, tri različne paste kot PZT prevleko nanesli na aluminij in polietilen tereftalat (PET). Hidrofobnost pripravljenih PZT kompozitov so avtorji ugotavljali z merjenjem kontaktnega kota oz. kota omakanja nastalim med kapljico vode in površino kompozitnih materialov PZT + PVB, PZT + PMMA in PZT + PS. Prav tako so kot omakanja določili pri kapljici glicerina, špirita in olivnega olja, nastali na površini izdelanih PZT kompozitov. Nazadnje so izdelali še mikrokanalski model z uporabo programskega orodja COMSOL Multiphysics na površini PZT + PMMA in izvedli simulacijo z uporabo električnega vzbujanja na vzorčnih elektrodah. Z mikrokanalsko simulacijo so dosegli različne deformacije v obliki valov. Predlagana aplikacija bi lahko bila uporabna za prenos biodelcev.

Ključne besede: piezoelektrični nanokompoziti, mikrohidravlični sistemi, kontaktni kot, hidrofobnost, omakanje, mikrokanal, biodelci

\section{INTRODUCTION}

Piezoelectric nanocomposites have been the focus of the development of the microdevices and micro-components in the past few decades. Piezoelectric materials are preferable because of their capability to transform the biological, chemical or mechanical response to an electrical signal by using the piezoelectric or piezoresistive effect. It has become a new trend in MEMS

*Corresponding author's e-mail:

y.patel@ktu.lt (Yatinkumar Patel) devices that are used for medical/medicine purposes because it promises high performance with a good accuracy level. ${ }^{1,2}$ The use of piezocomposites is reported to develop microchannels, micropumps, biosensors, microneedles. ${ }^{3}$ Recently, the most important development in the field is a micro electromechanical system (MEMS) and a nano electromechanical systems (NEMS) in a microfluidic drug-delivery system. ${ }^{4}$ Moreover, piezoceramics are some of the most multifunctional materials to produce actuators, sensors and transducers. Hence, piezoceramics are also used in the production of 
high-accuracy and precise printer heads, fuel injectors, ecograms and energy-harvesting devices. ${ }^{5-8}$ Hydrophobicity is the property of a liquid molecule that is an intermolecular force from a mass of water. It plays a significant role in applications in the industrial level as well as medical. Also, it is an important term in the field of bioscience, microhydraulic devices and MEMS (micro-electromechanical systems) development. ${ }^{9}$ It has significance in oil recuperation, grease, fluid covering, paint enterprises, and printing. ${ }^{10,11}$ In recent years there has been interest in the investigation of surfaces incorporating superhydrophobic and super hydrophilic. Because of their possible application in self-cleaning, nanofluidic, electrowetting and to determine the properties of the liquid. A study of the wettability and hydrophobicity involves primary data as the contact angle study, which is useful to know the degree of wetting, while the liquid is interacting with solid surfaces. There will be three possible conditions happening with small contact angles of less than $\left(<90^{\circ}\right)$, which indicates high wettability of the hydrophilic surface, while the angle is larger than $\left(>90^{\circ}\right)$ indicates a low wettability, which means a hydrophobic surface. ${ }^{12}$ The hydrophobicity gives less obstruction from the water, which is the main purpose behind the reduced efficiency of electrical devises, particularly for piezoelectric polymers. The profoundly hydrophobic surface could make a natural semiconductor material progressively steady and lead to broad uses of this material. ${ }^{13,14}$ Current strategies to prepare a hydrophobic surface depend on the post-adjustment of the surfaces..$^{15,16}$ Lately, numerous hydrophobic materials have been created using different segments, for example, polypropylene surfaces, polystyrene, polyurethane and poly(vinyl chloride), by using different methods. ${ }^{17,18}$ It was discovered that electrospinning is a popular method to adjust the wetting behaviour of a polymer surface. ${ }^{19,20}$ A predominant hydrophobic piezoelectric solid for broad applications has barely been reported. It is new in the field of nanotechnology, sensors which are working in liquid environment studies and nanoscience development because of the occurrence of many materials in the past few years. (e.g., graphene, carbon nanotube, boron nitride nano mash etc.). ${ }^{21}$

In this paper three different types of piezoelectric composite materials with a polymer composition (PVB, PS and PMMA) are investigated and display hydrophobic properties. hydrophobicity plays an important role in biosensors, which are working in the viscous (liquid) environment. The hydrophobicity investigation was made for PZT composite materials (PVB, PS, and PMMA) with different liquids (distilled water, glycerin, spirit, and olive oil). For hydrophobicity, the identification of these PZT composite materials simplified the experimental setup, which has been designed to measure the contact angle, because a contact-angle measurement is a convenient method for surface identification, when either it is hydrophobic or hydrophilic. ImageJ (DropSnake plugins) was used to analyse the images for the contact angle, which is formed by liquid drops on the PVB, PS, and PMMA composite surface. Moreover, the influence of different coating thickness of PZT composite material and different base materials on contact angle was investigated.

\section{EXPERIMENTAL PART}

\subsection{PZT composite material synthesis}

An oxalic acid-water $\left(\mathrm{C}_{2} \mathrm{H}_{2} \mathrm{O}_{4}\right)$ based nanopowder of lead zirconate titanate $\left(\mathrm{Pb}(\mathrm{Zrx}, \mathrm{Ti1}-\mathrm{x}) \mathrm{O}_{3}\right)$ with PZT $(58 / 42)$ was utilized. The chemical compound of the PZT (52/48) solution was lead (II) acetate $\left[\mathrm{Pb}\left(\mathrm{NO}_{3}\right)_{2}\right]$, titanium butoxide $\left[\mathrm{Ti}\left(\mathrm{C}_{4} \mathrm{H}_{9} \mathrm{O}\right)_{4}\right]$, and zirconium butoxide $\left[\mathrm{Zr}\left(\mathrm{OC}_{4} \mathrm{H}_{9}\right)_{4}\right]$. Alternate reagents utilized were oxalic acid, deionized water, acetic acid, and an ammonia solution. Lead (II) acetate $\left[\mathrm{Pb}\left(\mathrm{NO}_{3}\right)_{2}\right](8.26 \mathrm{~g})$ was mixed with $100 \mathrm{~mL}$ of water. Then in the same mixture of liquid acetic acid was poured and the solution of the mixture was warmed at $50{ }^{\circ} \mathrm{C}$ and blended to dissolve. Thirty-two grams of oxalic acid was diffused in $500 \mathrm{~mL}$ of water, then blended with the titanium butoxide (5.1 g) and zirconium butoxide (7.65 g) at a combination of $80 \%$. Thereafter, the solution of lead acetate was combined with the titanium butoxide and zirconium butoxide solution. The last solution was alkalized with $25 \%$ ammonia solution to $\mathrm{pH} 9-10$ and mixed for 60 minutes. The precipitate of the solution was separated in a vacuum and during filtration, it was washed with water and acetone. The material was dried at $100{ }^{\circ} \mathrm{C}$ for half of the day after the separation process. The powder was warmed at $1000{ }^{\circ} \mathrm{C}$ for 9 hours. Next, the PZT powder was grinded and blended with $20 \%$ solution of polyvinyl butyral in benzyl alcohol blended under defined conditions: $80 \%$ of PZT and $20 \%$ of the binding material. Finally, the coating of paste was made on a base material (aluminum and polyethylene terephthalate (PET)) using a screen-printing technique.

Thus, for the contact-angle measurement the specimen was prepared according to the screen-printing technique for the experimental measurement of the contact angle, three different PZT composites were produced with the PZT nanopowder and three different binding polymers polyvinyl butyral (PVB), polystyrene (PS) and polymethyl methacrylate (PMMA). The properties of the binding polymer are presented in Table 1.

Table 1: Properties of binding polymers

\begin{tabular}{|l|c|c|c|}
\hline \multicolumn{1}{|c|}{ Properties } & PVB & PMMA & PS \\
\hline Tensile strength, $\mathrm{MPa}$ & $\geq 20$ & $48-76$ & $32-44$ \\
\hline Poisson's ratio & $0.45-0.49$ & $0.35-0.4$ & $0.4-0.41$ \\
\hline Density, kg/m ${ }^{3}$ & 1070 & 1170 & 1050 \\
\hline Young's modulus, GPa & 0.05 & 3.1 & 2.7 \\
\hline
\end{tabular}


Using these properties of the binding polymers, the density of the used composite material was calculated. The density of different PZT composite materials is presented in Table 2.

Table 2: Density of composite materials

\begin{tabular}{|c|l|c|}
\hline Sr. no. & \multicolumn{1}{|c|}{ Composite material } & Density \\
\hline 1 & $80 \%$ PZT+20\% PVB & $6294 \mathrm{~kg} / \mathrm{m}^{3}$ \\
\hline 2 & $80 \%$ PZT+20\% PMMA & $6314 \mathrm{~kg} / \mathrm{m}^{3}$ \\
\hline 3 & $80 \%$ PZT $+20 \%$ PS & $6290 \mathrm{~kg} / \mathrm{m}^{3}$ \\
\hline
\end{tabular}

A modulus of elasticity of $6.3 \mathrm{GPa}$ was obtained for the PZT nanocomposite with PMMA binding material, while PS and PVB had lower elasticity moduli of 5.3 and $3.9 \mathrm{GPa}$, respectively. ${ }^{22} 80 \%$ of the nanocomposite material was PZT nanoparticles (Young's modulus 63 $\mathrm{GPa}$ ), while the portion of binding material was $20 \%$. Because of this, the modulus of flexibility was decreased multiple times.

\subsection{Specimen preparation}

For the contact-angle measurement the specimen was prepared with PZT nanopowder and three different binding polymers polyvinyl butyral (PVB), polystyrene (PS) and polymethyl methacrylate (PMMA). Moreover, to observe the influence of different base materials on the contact angle, two different types of base material were used Aluminum natural sheet and polyethylene terephthalate (PET), as shown in Figure 1.

Also, the thickness of the coating for the PZT binding polymer is different for each base material in order to examine the influence of the different thickness of the coating on the contact-angle measurement. Thus,
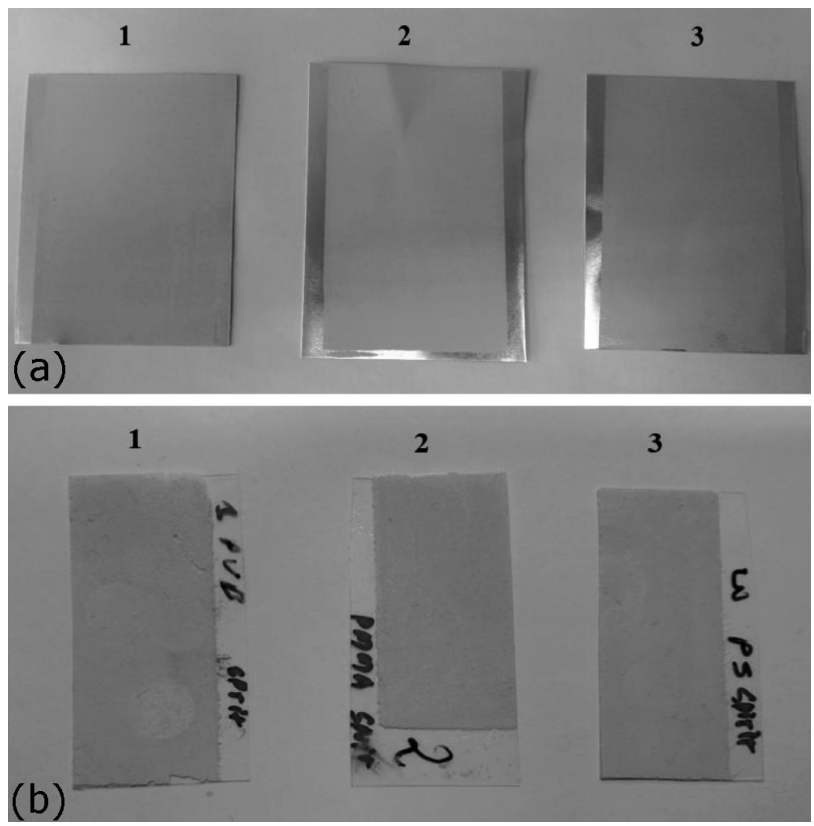

Figure 1: Multilayer specimen with: a) aluminum base material and b) with PET different base materials are also used to observe the different base material's influence on the measurement. The geometrical dimensions of the specimens are presented in Table 3 .

Table 3: Dimension of specimens

\begin{tabular}{|c|c|c|}
\hline \multirow{2}{*}{ Specimen } & \multicolumn{2}{|c|}{ Base material } \\
\cline { 2 - 3 } & $\begin{array}{c}\text { Aluminum, coating } \\
\text { thickness (total), } \mu \mathrm{m}\end{array}$ & $\begin{array}{c}\text { PET, coating } \\
\text { thickness (total), } \mu \mathrm{m}\end{array}$ \\
\hline PZT + PVB & $20(310)$ & $50(140)$ \\
\hline PZT + PS & $20(310)$ & $50(140)$ \\
\hline PZT + PMMA & $20(310)$ & $50(140)$ \\
\hline
\end{tabular}

Four different liquids, i.e., water, spirit, glycerin and olive oil, were used in the experiment in order to determine the hydrophobic properties of the surface with different liquids. The properties of the different liquids are presented in Table 4.

Table 4: Properties of liquids

\begin{tabular}{|c|c|c|c|}
\hline Sr. no. & Liquids & $\begin{array}{c}\text { Surface tension, } \\
\text { dyne/cm }\end{array}$ & $\begin{array}{c}\text { Density, } \\
\mathrm{kg} / \mathrm{m}^{3}\end{array}$ \\
\hline 1 & Water & 72.8 & 997 \\
\hline 2 & Glycerin & 64.2 & 1260 \\
\hline 3 & Spirit & 26.02 & 793 \\
\hline 4 & Olive oil & 34.76 & 888.89 \\
\hline
\end{tabular}

\subsection{Contact-angle measurements for hydrophobic analyses of PZT composites}

The experiment was performed at the Institute of Mechatronics and the Department of Mechanical Engineering, Kaunas University of Technology. The purpose of this experiment was to understand the hydrophobic properties of different PZT composite materials because liquid behaviour differs on the various surfaces, so the easiest way to determine the behavior of the liquid on the solid surface was by a contact-angle measurement. In this experiment, the freely available image-analysis software platform ImageJ was used for its ever-expanding flexibility. This software has three plugins to measure the contact angle, including contact-angle analysis, low bond axisymmetric drop shape analysis (LB-ADSA) and DropSnake.

The experimental setup presented in Figure 2 for the contact-angle measurements of the hydrophobic material consist of: (1) specimen, (2) adjustable specimen holder, (3) drop on specimen, (4) double convex lenses, (5) Guppy F-503 B\&W CMOS camera, (6) adjustable camera holder, (7) computer system with live image of drop with image-processing software to analyze a captured image. The optical parts consist of camera (Guppy F-503 B\&W CMOS camera specification of camera: pixel size: 5,038,848, Resolution: 2592(h) 1944 (v), sensor size: $1 / 2$ inch, sensor type: CMOS, connection: 1394A, speed: 7.5 frames/sec with $2592 \times 1944$ resolution and 60 frames/sec with $640 \times 480$ resolution) and optical lenses with a focal length of $600 \mathrm{~mm}$ (holo- 


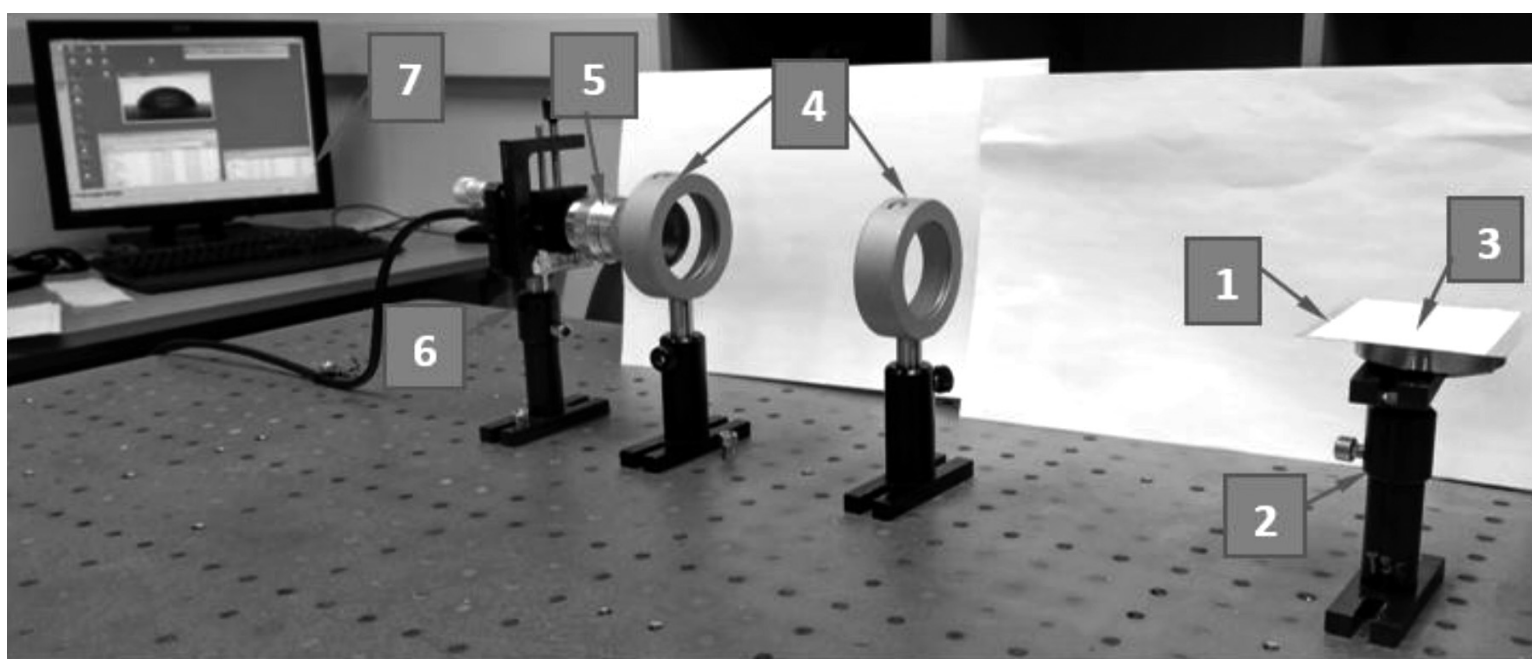

Figure 2: Experimental setup for contact-angle measurement

graphic and optical measurement laboratory, double convex lenses with $50 \mathrm{~mm}$ diameter) that is placed between the camera and the sample. The pipet used for the dispensing drop for different liquids. The pipet capacity is $5 \mathrm{~mL}$. Each subdivision is divided into $0.1 \mathrm{~mL}$ with a blue color code scale. The permitted drawing error for the pipet is $\pm 0.030 \mathrm{~mL}$.

The experiment was performed with an ambient light source in a dark laboratory room and the light settings are arranged to make the liquid drop appear black, which is necessary for measurement accuracy as well as for the image analysis. The light conditions are fully arranged to avoid any reflection of the light that spoils the measurement. Also, precautions were taken to prevent the drops polluted by air impurities such as dust and particles.

An illustration of the critical distance between camera, lenses and the drop of liquid presented in Figure 3, which is very important during the experiment, to maintain the stability of image quality to obtain accurate results. All the parts are placed on the stable surface table for an accurate measurement of the contact angle. Thus, there are two optical lenses placed between the camera and the specimen for exact focus on the drop. Also, lenses are kept stable and fixed. The camera fixed on the adjustable camera holder for adjusting height respect to the drop. While the specimen fixed on the adjustable specimen holder for the stable focus on the drop and to adjust the height of the specimen for excellent focused and good-quality image.

Firstly, the height of the specimen holder was adjusted according to parallel camera vision for the accurate position of the drop image. Then drop of distilled water $0.02 \mu \mathrm{l}$ diffused from the pipet to the PVB surface from the height $15 \mathrm{~mm}$ and the quantity of the diffused drop was kept constant for each drop of measurement and for all three PZT composite surfaces for all different liquids. Right after, the stabilization of the drop image was captured by the camera. Captured images were analyzed using ImageJ DropSnake plugins provided by Wayne Rasband (retired from NIH). By using those plugins, we started to put 7 knots from the left lower end to the right lower end along the profile of drop should cover inside all the knots. Then clicking twice on the image that will demonstrate the rough estimated value of the angle left-hand and right-hand side. Then, by adjusting the knots to achieve exact profile, then click on the fast snake button that will also show the red profile of drop and angles if it appears

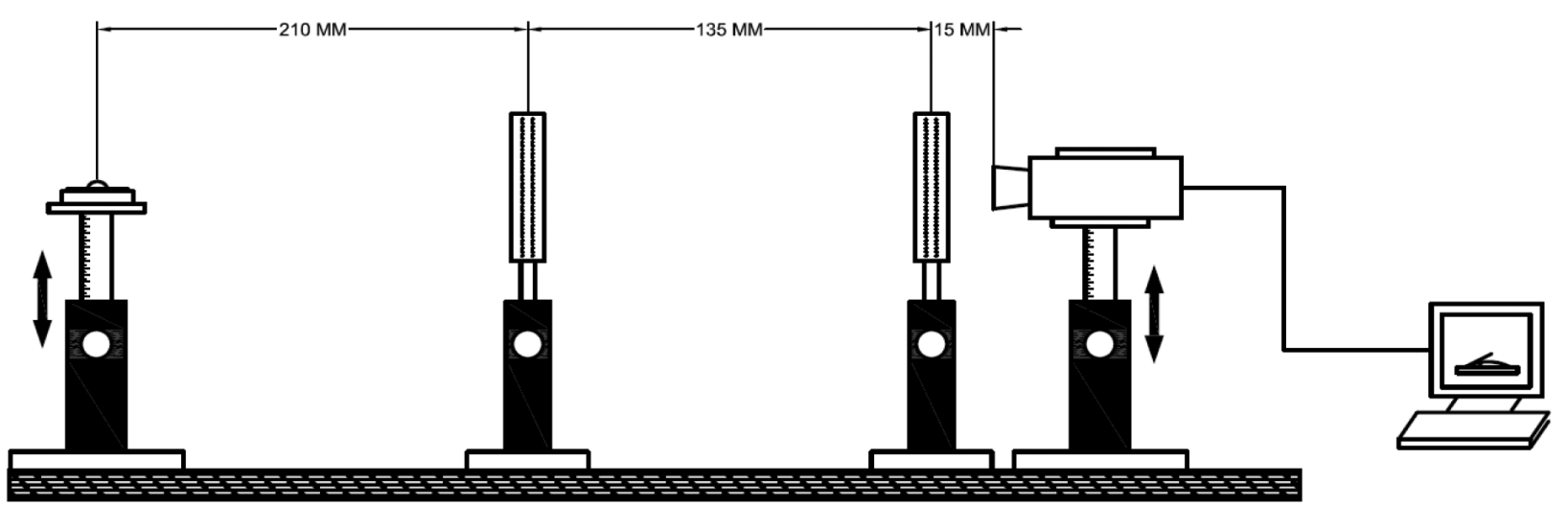

Figure 3: Ilustration of the critical distance between the important parts (camera, lens, and specimen with a drop) 


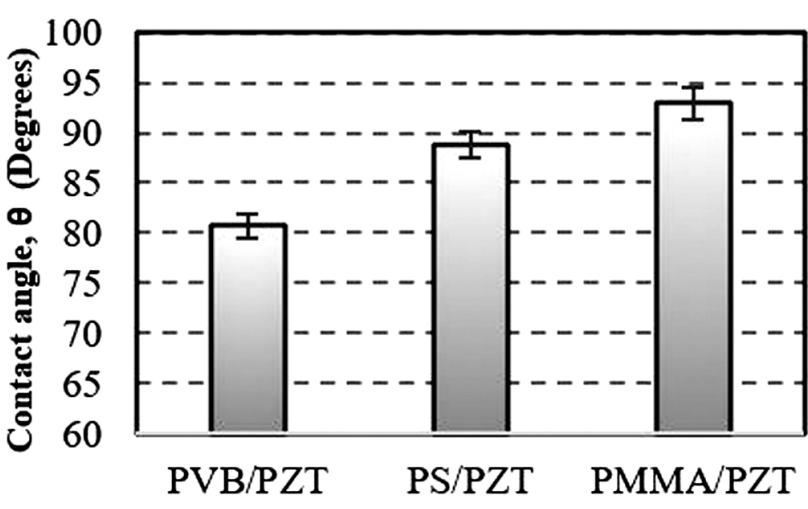

Figure 4: Mean contact angle of water droplet on three different PZT polymer surfaces

exact to the drop profile, then click on the green play button for redefining the drop profile and accept it. It will indicate the exact value of the left- and right-hand values, as well as the profile of the drop.

A calculation of the confidence level interval for the error in measurement was made using Equation 1. The value of $\mathrm{Z}$ was taken from the normal distribution 1.96, because the measured values lie within the range of the standard deviation of the mean. Also, the standard error of the mean value was calculated using Equation (2):

$$
\text { Confidance interval }=\bar{x} \pm Z \frac{s}{\sqrt{n}}
$$

where, $\bar{x}=$ average of measurement, $Z=1.960$ constant for accuracy level $95 \%, s=$ standard deviation and $n=$ number of measurements.

$$
\text { Standard error of mean }\left(\sigma_{\mathrm{m}}\right)=\frac{s}{\sqrt{n}}
$$

where, $s=$ standard deviation and $n=$ number of repetition of measurements (i.e., the rate of repetition was 15).

\section{RESULTS AND DISCUSSION}

The drop of water tested on three different PZT polymer multilayer specimens: polyvinyl butyral (PVB), poly (methyl methacrylate) (PMMA) and polystyrene (PS). Each sample of drop measurement on polymer was

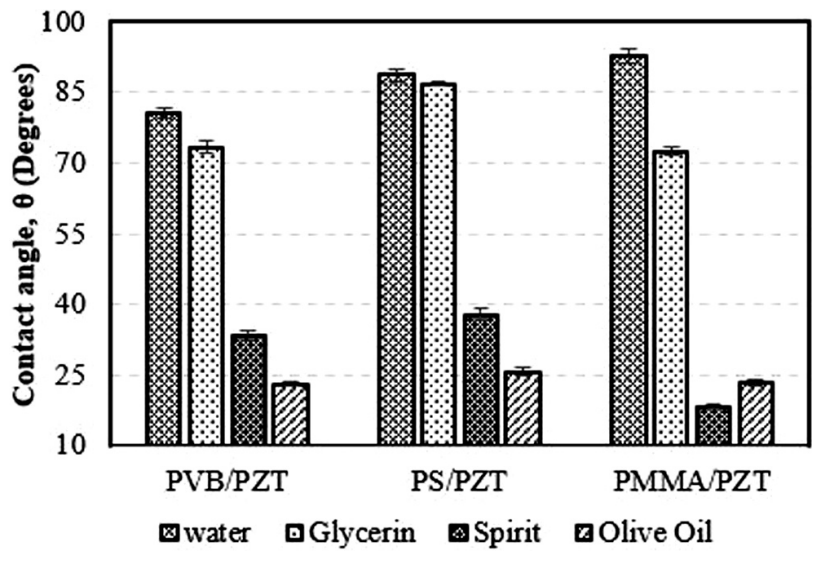

Figure 6: Mean contact angle with different liquids on three different PZT composite polymer surfaces

made using the same parameter a and the images were analyzed several times. The mean value of the contact angle $(\theta)$ measured for the water drop on the multilayer specimen of PZT + PVB, PZT + PS, and PZT + PMMA were $80.71 \pm 0.29^{\circ}, 88.88 \pm 0.33^{\circ}$, and $92.94 \pm 0.40^{\circ}$, respectively, and graphically presented in Figure 4.

Ilustration of the water drop tested on three polymer composite materials is presented in Figure 5.

From the measured values of the contact angle $(\theta)$ the maximum angle was observed with PZT + PMMA is $92.94^{\circ}$ with an error of $\pm 0.40^{\circ}$. The lowest contact angle was observed with PZT + PVB is $80.01^{\circ}$ with a measurement error of $\pm 0.29^{\circ}$. The measured value of the contact angle for PZT $+\mathrm{PS}$ is $88.8^{\circ}$, with an error of measurement of $\pm 0.33^{\circ}$ it falls between the measure value of PMMA and PVB. So, according to the literature review, it could be stated that PMMA falls in the range of hydrophobic material with water. ${ }^{23,24}$ PVB and PS show contact angles less than $90^{\circ}$, so can be considered as a hydrophilic surface with water.

The measured contact angles for the spirit drop on different polymer binding material are presented in Figure 6. The measured values of contact angle for PZT $+\mathrm{PVB}, \mathrm{PZT}+\mathrm{PS}$, and PVB + PMMA are $33.43 \pm 0.45^{\circ}$, $38.01 \pm 0.48^{\circ}$, and $18.48 \pm 0.12^{\circ}$, respectively. From the results it is possible to state that all three polymer composite materials are hydrophilic with the spirit.

$$
\mathrm{R}=88.38^{\circ} \quad \mathrm{L}=93.6^{\circ} \quad \mathrm{R}=92.3^{\circ}
$$

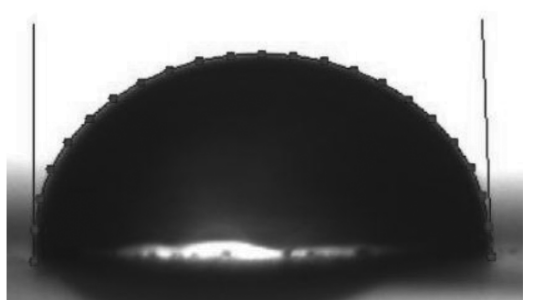

$\mathbf{P S} / \mathbf{P Z T}$

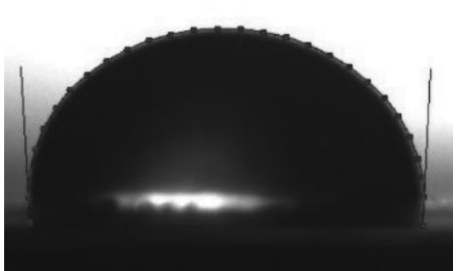

PMMA/PZT

Figure 5: Water-drop profile on the PZT composite material surface polynomial fit 


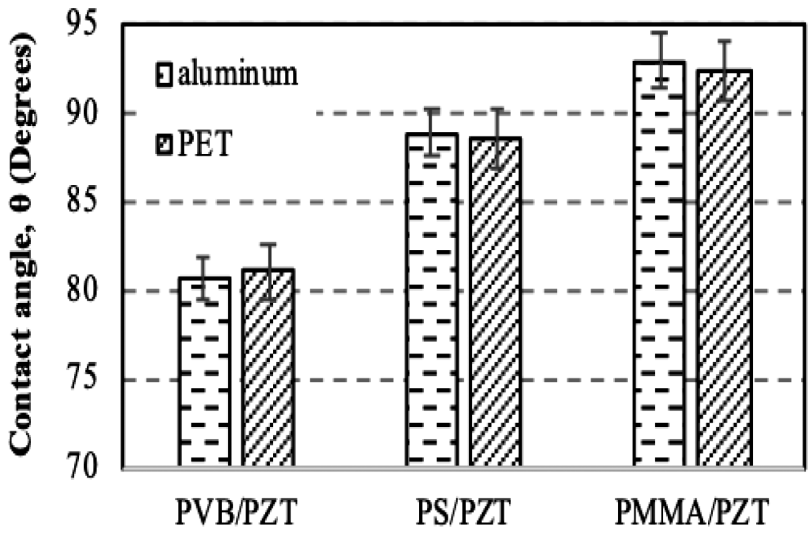

Figure 7: Comparison of WCA on Different base material

For olive oil the different PZT polymer composite surfaces of PVB, PS, and PMMA are presented in Figure 6. As seen in the graph the measured values of the contact angle for PVB, PS, and PMMA are $23.18 \pm 0.10^{\circ}$, $25.86 \pm 0.29^{\circ}$, and $23.57 \pm 0.18^{\circ}$, respectively. There is no significant statistical difference between the results.

The experiment was performed on different PZT polymer composite material (PVB, PS, and PMMA) with different liquids (water, glycerin, spirit, and olive oil). The obtained results show that only PMMA has hydrophobic properties with water. From the plot in Figure 6 the contact angle for PMMA with water $\left(92.94^{\circ}\right)$ is only more than $90^{\circ}$. All the other polymer composite materials show contact angles less than $90^{\circ}$ and the lowest contact angle was found for olive oil $\left(18.48^{\circ}\right)$ on the surface of PZT + PMMA.

In order to know the influence of the different base materials on the contact angle the experiment was performed with two different base materials, aluminum and PET, presented in Figure 7. From the experiment angle measured for the drop of water on PZT + PVB binding polymer with aluminum and PET base material is $81.03 \pm 0.4^{\circ}$ and $80.71 \pm 0.42^{\circ}$, respectively. It is only a difference of $0.4 \%$. For PZT + PS with aluminum and PET base material it is $88.47 \pm 0.41^{\circ}$ and $88.8 \pm 0.33^{\circ}$, respectively. The difference in contact angle is just
$0.37 \%$. PZT + PMMA has the highest contact angle among the three polymer binding materials. The observed values are $92.43 \pm 0.43^{\circ}$ and $92.94 \pm 0.4^{\circ}$ with the aluminum and PET base material, respectively. It is only a difference of $0.55 \%$. From the results there is no influence of base material on the water-angle measurement.

In order to understand the environmental effect (temperature, air/impurities) on the contact angle measurement a time dependence study was performed for the water droplet. To observe the change in WCA (water contact angle) images were captured for each drop sample on various polymer composite surfaces at different time intervals. Images were captured after $10 \mathrm{~s}, 120 \mathrm{~s}$, and $240 \mathrm{~s}$ for every drop sample. The result are presented in Figure 8. Initially, after $10 \mathrm{~s}$ measured WCA of PZT $+\mathrm{PVB}$ is $80.01^{\circ}$, after $120 \mathrm{~s}$ a $1.9^{\circ}$ change observed and it was gradually decreased to $76.96^{\circ}$ after $240 \mathrm{~s}$. So, it is possible to state WCA of PVB has gradually decrement of $2^{\circ}$ after every $120 \mathrm{~s}$. Moreover, a similar effect has been observed with PS binding polymer initially $88.80^{\circ}$ observed then it decreased to $86.90^{\circ}$ and finally, after $240 \mathrm{~s}$, it decreased to $85.64^{\circ}$. For the PMMA binding polymer it was $92.94^{\circ}$ at $10 \mathrm{~s}$, it decreases to $90.73^{\circ}$ after $120 \mathrm{~s}$ and at last, after $240 \mathrm{~s}$ it was observed at $89.44^{\circ}$. So, for all three polymer binding materials, no significant change was observed during first $120 \mathrm{~s}$, but there is an observable difference in the contact angle between the initial and final measurement.

To check the possible application of the proposed PZT composite materials we decided to prepare a microchannel with controllable parameters using the thermal reapplication process. A model of the microchannel is presented in Figure 9.

The geometrical dimensions of the microchannel (Figure 9a) are the length $(L)=200 \mu \mathrm{m}$, period $(P)=20$ $\mu \mathrm{m}$, total thickness $(T)=20 \mu \mathrm{m}$, depth of the inner slot (d) $=10 \mu \mathrm{m}$, width of the slot $(w)=10 \mu \mathrm{m}$, and thickness of the two ridge $(2 r)=10 \mu \mathrm{m}$ and radius at the inner corners are $D=2 \mu \mathrm{m}$. The investigation of the micro-
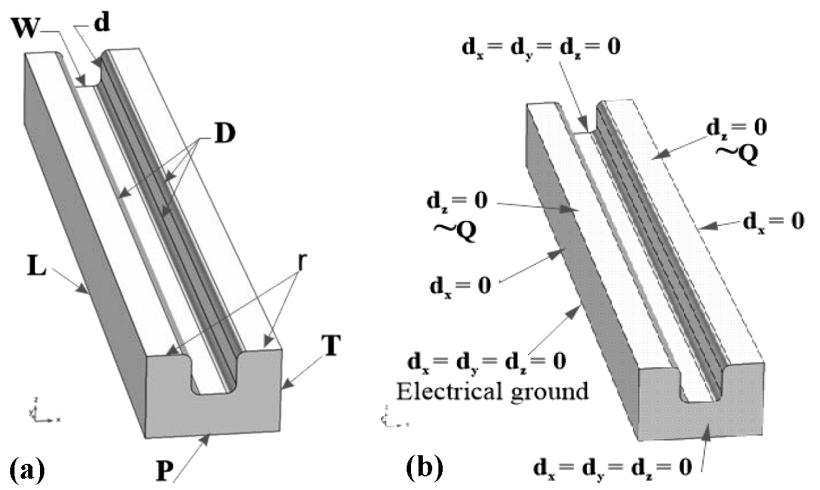

Figure 9: a) Dimensions of the finite-element model of the microchannel and b) the boundary condition of the finite-element model of the microchannel 


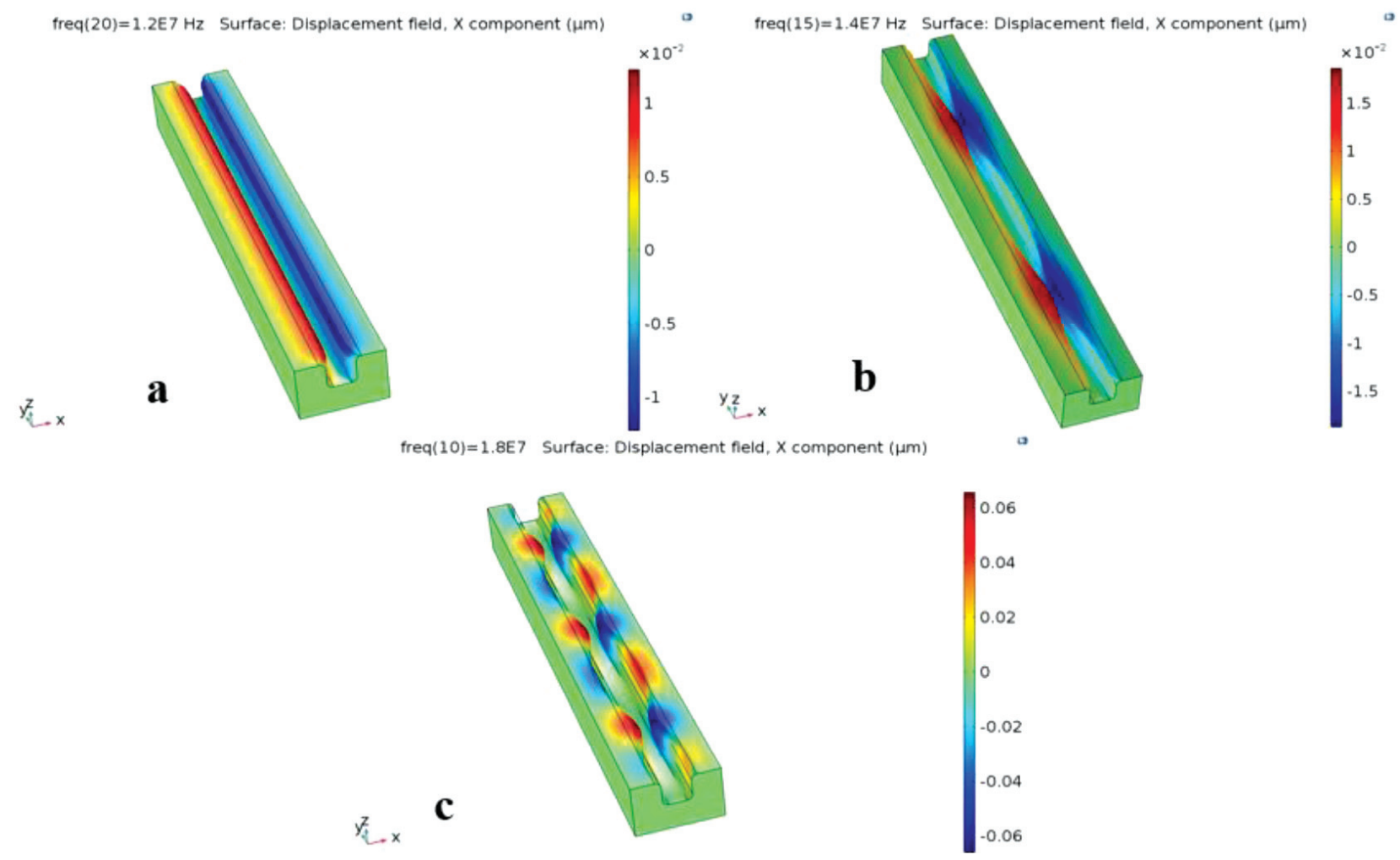

Figure 10: a) Surface deformation of microchannel periodically excited at $12 \mathrm{MHz}$ frequency, b) microchannel periodically excited at $14 \mathrm{MHz}$ and c) microchannel periodically excited at $18 \mathrm{MHz}$ frequency with visualized $\mathrm{X}$ component of the displacement field

channel was made using the COMSOL Multiphysics 5.4 simulation software.

Just one part of the microchannel was analyzed with the symmetrical boundary conditions because this is a periodic system. The boundary conditions (Figure 9b) were applied to the finite-element model and the left and right surfaces of the microchannel were kept fixed by using rollers. The front and back surfaces of the microchannel were totally in the fixed condition because these surfaces are connected to the fluid container. The bottom surface of the model will be connected to the other element of the sensor; therefore, it is also in an unmovable fixed condition and its serves as an electrical ground. The top portion of the microchannel is enclosed by electrodes and a high-strength transparent layer. It allows for a visual inspection of the fluid flow and confirms that the pressure inside the channel is high.

Then the system of the microchannel is excited by applying the sinusoidal alternating electrical potential of $20 \mathrm{~V}$. There are three sample tests done for the dynamic response of the suggested microchannel at a different frequency.

The total deformation and $\mathrm{X}$ component of the displacement field of the electrically excited microchannel system at $12 \mathrm{MHz}$ frequency (Figure 10a) shows that the shape of the channel is deformed and it looks like a mechanical valve, which means the cross-section area of the channel is eventually increased or decreased throughout the length of the microchannel. When the frequency

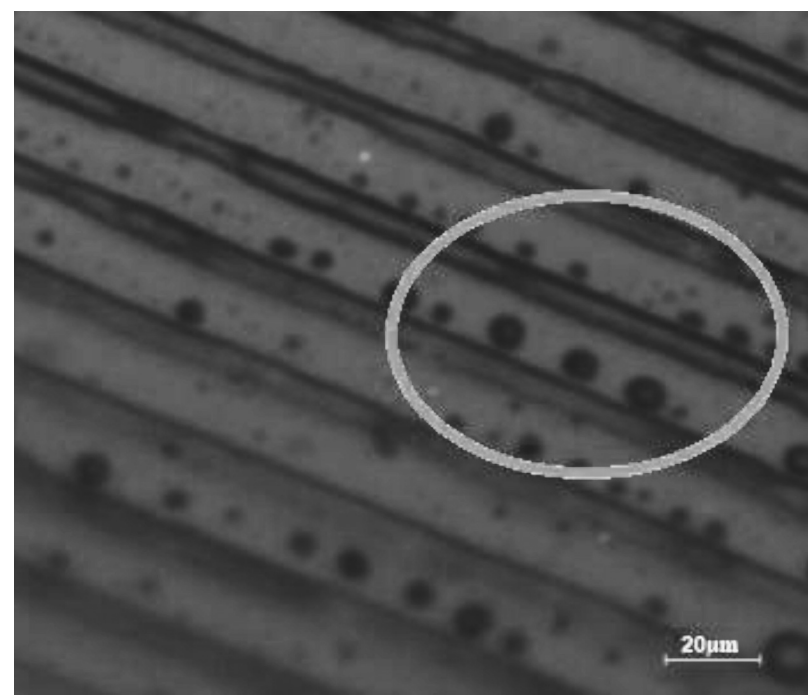

Figure 11: Microscope image with water particles in the microchannel

is increased to $14 \mathrm{MHz}$, then the cross-section of the microchannel starts to divide into two segments (Figure 10b) with different concentrations of bioparticles. While the frequency increased to $18 \mathrm{MHz}$, the cross-section of the microchannel actually shows that it is divided into four segments with different concentrations of bioparticles (Figure 10c). From the simulation and hydrophobicity results, it could be possible to state that the developed material PZT+PMMA could be usable for the 
development of efficient and durable devices in microhydraulic devices. A possible application is presented in Figure 11.

As shown in Figure 11, the water particles are inside the microchannel, which is marked inside the orange circle. the period of the microchannel is $20 \mu \mathrm{m}$, chosen for the simulation. So, from the image it is clear and possible to state that the proposed material is useful for the development of microhydraulic devices in biomedicine.

\section{CONCLUSIONS}

An investigation of the hydrophobic properties of a PZT composite polymer was performed. Experimental results showed the contact angles $(\theta)$ for the PZT composite material PVB, PS, and PMMA with water are $80.71 \pm 0.4^{\circ}, 88.08 \pm 0.33^{\circ}$, and $92.94 \pm 0.4^{\circ}$, respectively. Also, the contact angle was measured with different liquids, and the results are with glycerin PVB $73.49 \pm 0.5^{\circ}$, PS $-86.92 \pm 0.18^{\circ}$, and $72.52 \pm 0.29^{\circ}$, with spirit PVB - $33.43 \pm 0.45^{\circ}$, PS - 38.01 $\pm 0.48^{\circ}$, and PMMA - $18.48 \pm 0.12^{\circ}$, and with olive oil PVB $23.18 \pm 0.10^{\circ}$, PS - $25.86 \pm 0.29^{\circ}$, and PMMA $23.57 \pm 0.18^{\circ}$. From the obtained values only the contact angle of the water drop is noted highest $\left(92.94 \pm 0.40^{\circ}\right)$ on the PZT + PMMA composite surface, which indicates the PMMA is the only hydrophobic material. Moreover, PVB, PS would be considered as hydrophilic materials with water. So, from the results, it is clearly stated that only the PMMA with PZT composite material surface is falling in the hydrophobic segment, and the rest of the surfaces are hydrophilic.

Moreover, it is found that there is no influence of the different thickness of the coating and the different base materials on the contact angle. A high Q factor of the proposed composite materials would permit it to effectively control the microdevice as microchannels.

The presentation of the microchannel simulated by COMSOL Multiphysics demonstrated that it could work in three modes: the valve mode that was closed for bioparticles when half-wavelength oscillation of $12 \mathrm{MHz}$ frequency was produced; bioparticle designing or trap mode when a full wavelength oscillation of $14 \mathrm{MHz}$ recurrence was created; and mode with free go for bioparticles when no vibrations were produced in the microchannel.

The experimental setup for the contact-angle measurement allows us to measure the $\mathrm{CA}$ with an accuracy level of $1.5^{\circ}$. It is possible to capture an excellent quality image due to the high-speed camera (60 fps) used. Also, the setup could be useful to measure the dynamic contact angle, time dependence, and advancing and receding contact angle. The used image-analysis software is a freely available platform (ImageJ). DropSnake plugins retuned the precise and stable values of the contact angle in both the relatively high $\left(\theta=90^{\circ}\right)$ and low $\left(\theta=40^{\circ}\right)$ regions. Also, it is possible to measure the contact angle for different solid substrates and liquids.

\section{Acknowledgments}

This research was funded by grant S-MIP-17-102 from the Research Council of Lithuania and by grant CZ.02.1.01/0.0/0.0/16_019/0000843 from the Ministry of Education, Youth and Sports of the Czech Republic and the European Union - European Structural and Investment Funds in the frames of Operational Programme Research, Development and Education - project Hybrid Materials for Hierarchical Structures.

\section{REFERENCES}

${ }^{1}$ An Approach to Mems Design, Microsystem Design, Kluwer Academic Publishers 2005, 15-28, doi:10.1007/0-306-47601-0_2

${ }^{2}$ S. Hardt, F. Schönfeld, Microfluidic technologies for miniaturized analysis systems, Springer, US (2007), 165, doi:10.1007/9780-387-68424-6

${ }^{3}$ K. K. Liu, R. G. Wu, Y. J. Chuang, H. S. Khoo, S. H. Huang, F. G. Tseng, Microfluidic systems for biosensing, Sensors, 10 (2010), 6623-6661, doi:10.3390/s100706623

${ }^{4}$ M. W. Ashraf, S. Tayyaba, A. Nisar, N. Afzulpurkar, MEMS based system for drug delivery. Proceedings, 6th International Conference on Emerging Technologies, ICET 2010, 82-87, doi:10.1109/ ICET.2010.5638375

${ }^{5}$ A. Safari, E. K. Akdogan, Preface. Piezoelectric and Acoustic Materials for Transducer Applications, Springer US 2008, 1-481, doi:10.1007/978-0-387-76540-2

${ }^{6}$ B. Jaffe, W. R. Cook, H. Jaffe, Barium titanate, In Piezoelectric Ceramics, Elsevier 1971, 53-114, doi:10.1016/b978-0-12-3795502.50009-0

${ }^{7}$ A. J. Moulson, J. M. Herbert, Electroceramics, Materials, Properties, Applications (2003), 576, doi:10.1002/0470867965

${ }^{8}$ J. Palosaari, M. Leinonen, J. Hannu, J. Juuti, H. Jantunen, Energy harvesting with a cymbal type piezoelectric transducer from low frequency compression. Journal of Electroceramics. 28 (2012), 214-219, doi:10.1007/s10832-012-9713-8

${ }^{9}$ Y. Yuan, T. R. Lee, Contact angle and wetting properties. Springer Series in Surface Sciences. 51 (2013), 3-34, doi:10.1007/9783-642-34243-1_1

${ }^{10} \mathrm{O}$. Gharbi, M. J. Blunt, The impact of wettability and connectivity on relative permeability in carbonates: A pore network modeling analysis. Water Resources Research. 48 (2012) 12, doi:10.1029/ 2012WR011877

${ }^{11}$ Y. Q. Wang, H. F. Yang, Q. G. Han, L. Fang, S. R. Ge, in Advanced Materials Research 2011, 154-155, 1019-102, doi:10.4028/ www.scientific.net/AMR.154-155.1019

${ }^{12}$ G. Lamour, A. Hamraoui, A. Buvailo, Y. Xing, S. Keuleyan, V. Prakash, E. Borguet, Contact angle measurements using a simplified experimental setup. Journal of Chemical Education, 87 (2010) 12, 1403-1407. doi: 10.1021/ed100468u

${ }^{13}$ M. S. Islam, N. Akter, M. R. Karim, Preparation of superhydrophobic membranes by electrospinning of fluorinated silane functionalized pullulan, Colloids and Surfaces A: Physicochemical and Engineering Aspects, 362 (2010) 1-3, 117-120, doi:10.1016/ j.colsurfa.2010.04.004

${ }^{14}$ S. K. Papadopoulou, C. Tsioptsias, A. Pavlou, K. Kaderides, S. Sotiriou, C. Panayiotou, Superhydrophobic surfaces from hydrophobic or hydrophilic polymers via nanophase separation or electro- 
spinning/electrospraying. Colloids and Surfaces A: Physicochemical and Engineering Aspects. 387 (2011), 71-78, doi:10.1016/ j.colsurfa.2011.07.028

${ }^{15}$ F. L. Huang, Q. Q. Wang, Q. F. Wei, W. D. Gao, H. Y. Shou, S. D. Jiang, Dynamic wettability and contact angles of poly(vinylidene fluoride) nanofiber membranes grafted with acrylic acid. Express Polymer Letters, 4 (2010) 9, 551-558. doi:10.3144/expresspolymlett. 2010.69

${ }^{16}$ M. Yue et al., Erratum: Switchable hydrophobic/hydrophilic surface of electrospun poly (1-lactide) membranes obtained by CF 4 microwave plasma treatment, Applied Surface Science. 327 (2015), 93-99, doi:10.1016/j.apsusc.2015.01.145

${ }^{17}$ Y. C. Jung, B. Bhushan, Contact angle, adhesion and friction properties of micro-and nanopatterned polymers for superhydrophobicity. Nanotechnology, 17 (2006) 19, 4970-4980. doi:10.1088/ 0957-4484/17/19/033

${ }^{18}$ H. Y. Erbil, A. L. Demirel, Y. Avci, O. Mert, Transformation of a simple plastic into a superhydrophobic surface. Science, 299 (2003) 5611, 1377-1380, doi:10.1126/science.1078365

${ }^{19}$ J. Zhang, J. Li, Y. Han, Superhydrophobic PTFE surfaces by extension. Macromolecular Rapid Communications, 25 (2004) 11 1105-1108, doi:10.1002/marc.200400065
${ }^{20}$ M. T. Khorasani, H. Mirzadeh, Z. Kermani, Wettability of porous polydimethylsiloxane surface: Morphology study. Applied Surface Science, 242 (2005) 3-4, 339-345, doi:10.1016/j.apsusc.2004.08.035

${ }^{21}$ S. F. L. Mertens, A. Hemmi, S. Muff, O. Groning, S. De Feyter, J. Osterwalder, T. Greber, Switching stiction and adhesion of a liquid on a solid. Nature, 534 (7609) (2015), 676-679, doi:10.1038/ nature 18275

${ }^{22}$ A. Palevicius, G. Janusas, E. Cekas, Y. R. Patel, in Lecture Notes in Computer Science (including subseries Lecture Notes in Artificial Intelligence and Lecture Notes in Bioinformatics), Springer Verlag 2018, 49-58, 10814 LNBI, doi:10.1007/978-3-319-78759-6_5

${ }^{23}$ A. Arefin, J. H. Huang, D. Platts, V. D. Hypes, J. F. Harris, R. Iyer, P. Nath, Fabrication of flexible thin polyurethane membrane for tissue engineering applications. Biomedical Microdevices, 19 (2017) 4, doi:10.1007/s10544-017-0236-6

${ }^{24}$ P. Kumar, N. Khan, D. Kumar, Polyvinyl butyral (pvb), versetile template for designing nanocomposite/composite materials: a review. Green Chemistry \& Technology Letters, 2 (2016) 4, 185, doi:10.18510/gctl.2016.244 